\title{
ANÁLISE DO IMPACTO CHARPY EM COMPÓSITOS DE MATRIZ POLIMÉRICA REFORÇADA COM FIBRAS DE CÂNHAMO*
}

\author{
Anna Carolina Cerqueira Neves ${ }^{1}$ \\ Lázaro Araújo Rohen ${ }^{1}$ \\ Janaina da Silva Vieira ${ }^{1}$ \\ Carlos Maurício Fontes Vieira ${ }^{2}$ \\ Frederico Muylaert Margem ${ }^{3}$ \\ Sergio Neves Monteiro ${ }^{4}$ \\ Dhyemila de Paula Mantovani ${ }^{5}$
}

\section{Resumo}

As fibras sintéticas vêm sendo gradualmente substituídas por fibras naturais. Em comparação com a fibra sintética, fibra natural demonstrou vantagens econômicas e ambientais. Visto que apresenta características interfaciais com matrizes poliméricas que favorecem a absorção de energia de alto impacto pela estrutura. No entanto, até agora pouco foi avaliado sobre a fibra de cânhamo incorporada em matrizes poliméricas. Este estudo tem o objetivo de avaliar a resistência ao impacto deste tipo de compósito com matriz de poliéster reforçada com diferentes porcentagens de fibras de cânhamo. A resistência ao impacto aumenta proporcionalmente com a quantidade relativa de fibras incorporadas como reforço na matriz polimérica. Este desempenho foi relacionado com a dificuldade de ruptura imposta pelas fibras, resultante da interação da matriz de fibra de cânhamo / poliéster de forma a ajudar a absorção da energia de impacto.

Palavras-chave: Charpy; Teste de impacto; Fibra de cânhamo; Compósitos.

\section{CHARPY IMPACT TEST IN POLYESTER MATRIX COMPOSITES REINFORCED WITH HEMP FIBER}

\begin{abstract}
Synthetic fiber has been gradually replaced by natural fiber, such as lignocellulosic fiber. In comparison with synthetic fiber, natural fiber has shown economic and environmental advantages. The natural fiber presents interfacial characteristics with polymeric matrices that favor a high impact energy absorption by the composite structure. However, until now little has been evaluated about the hemp fiber incorporated in polymeric matrices. This study has the purpose of evaluate the impact resistance of this kind of polyester matrix composite reinforced with different percentages of hemp fibers. The impact resistance has substantially increased the relative amount of hemp fiber incorporated as reinforcement in the composite. This performance was associated with the difficulty of rupture imposed by the fibers resulting from the interaction of hemp fiber / polyester matrix that helps absorb the impact energy.

Keywords: Charpy; Impact test; Hemp fiber; Composites.

1 Graduando(a) em Engenharia Metalúrgica e de Materiais, bolsista de iniciação científica, LAMAV, UENF, Campos dos Goytacazes, Rio de Janeiro - Brasil.

2 Doutor em Engenharia e Ciência dos Materiais pela Universidade Estadual do Norte Fluminense Darcy Ribeiro. LAMAV, UENF, Campos dos Goytacazes, Rio de Janeiro - Brasil.

3 Pós doutorando em Ciência e Engenharia de Materiais, Pós-doutorado, LAMAV, UENF, Campos dos Goytacazes, Rio de Janeiro - Brasil.

4 Professor PhD, IME, Rio de Janeiro, Rio de Janeiro - Brasil

5 Mestranda em Engenharia e Ciência dos Materiais, LAMAV, UENF, Campos dos Goytacazes, Rio de Janeiro - Brasil.
\end{abstract}




\section{INTRODUCTION}

Natural fibers are steadily substituting synthetic fibers, particularly the common glass fiber, as the reinforced phase of polymeric composites in many engineering applications such as automobile interior components, cyclist helmets, housing panels and windmill fins (1-4). The lignocellulosic fibers obtained from vegetables offer societal, economical, environmental and technical benefits ${ }^{(5,6)}$ in comparison to the glass fiber as composite reinforcement. In particular, the impact resistance of a naturally flexible lignocellulosic fiber is a technical advantage over the brittle glass fiber in a situation of a crash event. This is the case of automobile parts such as the head-rest and the interior front panel that should not have a brittle rupture during an accident. In fact, the parts should be soft and able to absorb the impact energy without splitting in sharp pieces, to avoid injuring the passengers ${ }^{(6)}$.

Lignocellulosic fibers such as coir, flax, jute, ramie, curaua and sisal are currently being used in automobile composite parts that require both strength and toughness (4). The hemp fiber, although strong and flexible (7) has not yet been applied in composites for automobile components. Actually, the fibers obtained from the petiole of the hemp palm tree commonly used to fabricate ropes and baskets owing to its high strength. This has motivated the study of the mechanical characteristic of the fibers.

In spite of existing works on the properties of hemp fiber composites ${ }^{(8-9)}$, the impact resistance of continuous and aligned fiber reinforcing polymeric composites has yet to be evaluated. Therefore, the objective of the present work was to access the toughness through the energy absorbed by notched Charpy impact specimens of polyester composites reinforced with different amounts of continuous hemp fibers.

\section{EXPERIMENTAL PROCEDURE}

The material used in this work was untreated hemp fiber extracted from the stem hemp plant and polyester resin. Statistical analysis were performed on one hundred fibers randomly removed from the as-received the lot. Figure 1 shows the histogram for the distribution of hemp fiber diameters by considering 6 diameter intervals. From this distribution, presented elsewhere an average diameter of $0.065 \mathrm{~mm}$ was found for the as-received lot.

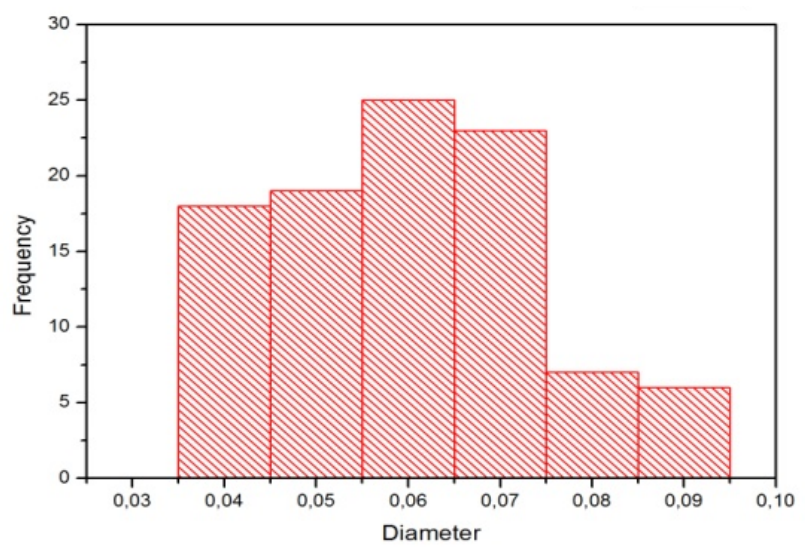

Figure 1. Distribution histogram for six diameter intervals. 
Several other hemp fibers were cleaned in water and dried at $60^{\circ} \mathrm{C}$ in a stove to be used as composite reinforcement. Continuous and aligned fibers were laid down, in separate amounts of 10,20 , and $30 \%$ vol, mixed with still fluid unsaturated polyester resin, in a mold made of steel with $62 \times 12.7 \mathrm{~mm}$ and $10 \mathrm{~mm}$ of thickness.

Unsaturated orthophitalic polyester resin mixed with $0.5 \%$ of methyl ethyl- ketone as hardener of still liquid resin was poured into the hemp fibers in the mold. A 24 hours cure at room temperature was allowed for these composite samples. After unmolded, the samples were cut following the ASTM D256 standard. Ten specimens for each percentage of hemp fiber composite were impact tested in a PANTEC pendulum, Fig. 2 , set in the Charpy configuration.
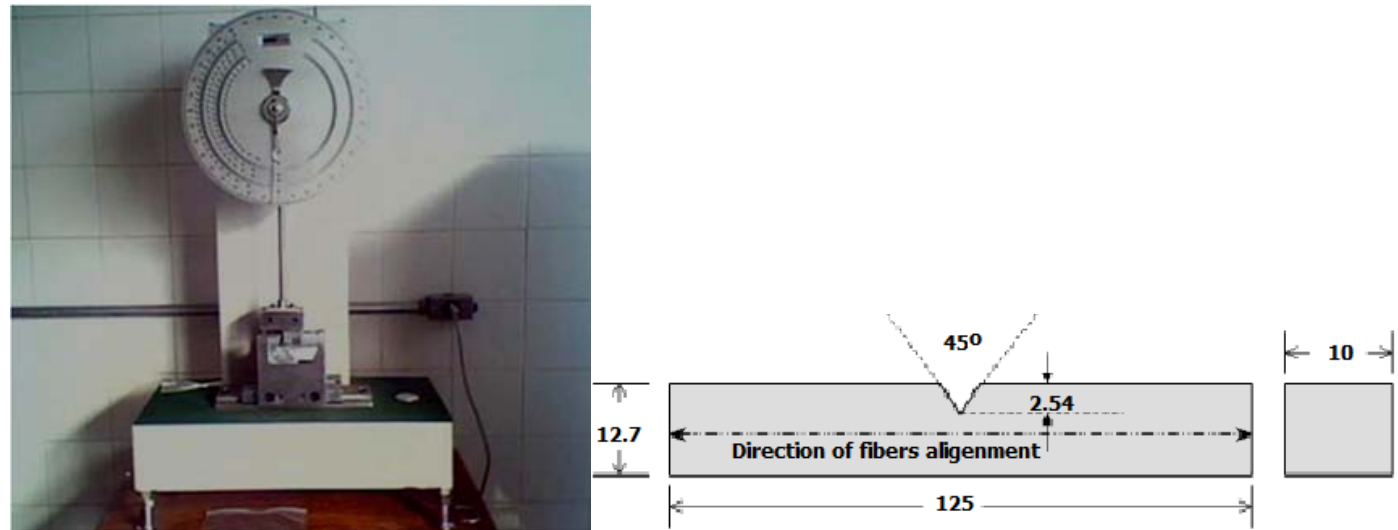

Figure 2: Charpy equipment and standard specimen schematic.

\section{RESULTS AND DISCUSSION}

Table 1 presents the results of Charpy impact tests of polyester matrix composites reinforced with different volume fractions of hemp fibers.

Table 1. Charpy impact energy for polyester composites reinforced with hemp fibers.

\begin{tabular}{|c|c|}
\hline $\begin{array}{c}\text { Volume Fraction of Hemp Fiber } \\
(\%)\end{array}$ & $\begin{array}{c}\text { Charpy Impact Energy } \\
(\mathrm{J} / \mathrm{m})\end{array}$ \\
\hline 0 & $14.9 \pm 0.60$ \\
\hline 10 & $78.7 \pm 2.58$ \\
\hline 20 & $87.1 \pm 7.51$ \\
\hline 30 & $139.05 \pm 8.21$ \\
\hline
\end{tabular}

Based on the results shown in Table 1, the variation of the Charpy impact energy with the amount of hemp fiber in the polyester composite is shown in Fig. 3. 


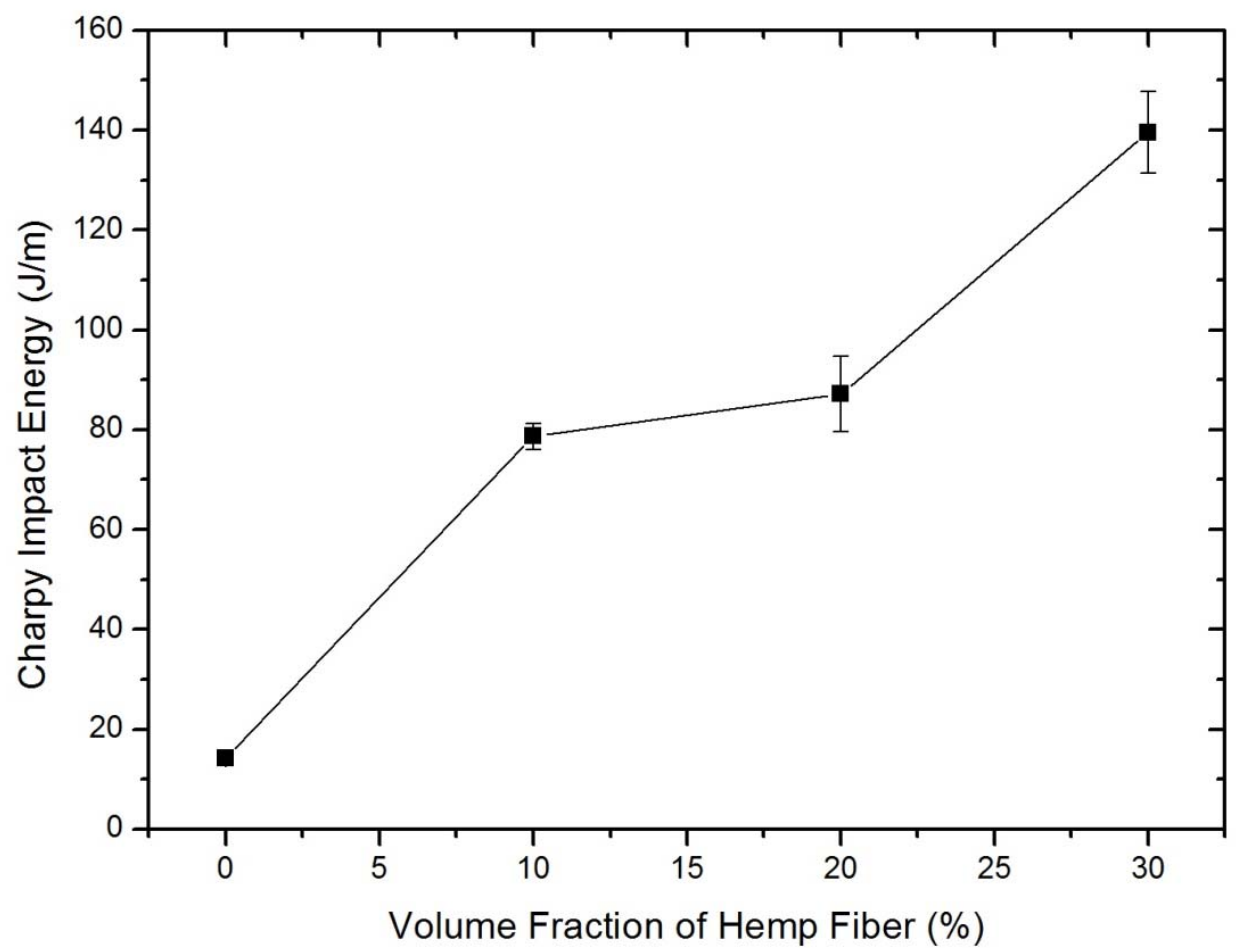

Figure 3. Charpy impact energy as a function of different volume fractions of hemp fiber.

In this figure it should be noticed that the hemp fiber incorporation into the matrix significantly improves the impact toughness of the composite. This improvement can be considered almost as increase with respect to the amount of hemp fibers.

The relatively high dispersion of values, given by the standard deviation associated with the higher fiber percentage points in Fig. 3, is a well known heterogeneous characteristic of the lignocellulosic fibers (11). The values shown in this figure are consistent with results reported in the literature (12-13). The reinforcement of a polymeric matrix with both synthetic ${ }^{(13-14)}$ and natural|(15-16) fibers increases the impact toughness of the composite.

In this work, using aligned hemp fibers, the impact toughness of $139.05 . \mathrm{J} / \mathrm{m}$ for $30 \%$ long hemp fibers. The greater impact resistance of the polyester in comparison with the polypropylene matrix could be one reason for the superior performance found in the present work. However, there are other important factors related to the impact fracture characteristic of polymeric reinforced with long and aligned natural fibers.

The relatively low interface strength between a hydrophilic natural fiber and a hydrophobic polymeric matrix contributes to an ineffective load transfer from the matrix to a longer fiber. This characteristic allow the system to absorb more energy because of the flexibility of the fiber that slide out of the matrix but do not breaks, what amplifies the energy needed to rupture the specimen ${ }^{(17)}$. The macroscopic aspects of the typical specimen ruptured by Charpy impact tests are shown in Fig. 4 . In this figure it should be noted that the incorporation of fiber results in a completely different rupture shape with respect to pure polyester $(0 \%$ fiber) in which a totally transversal rupture occurs. 


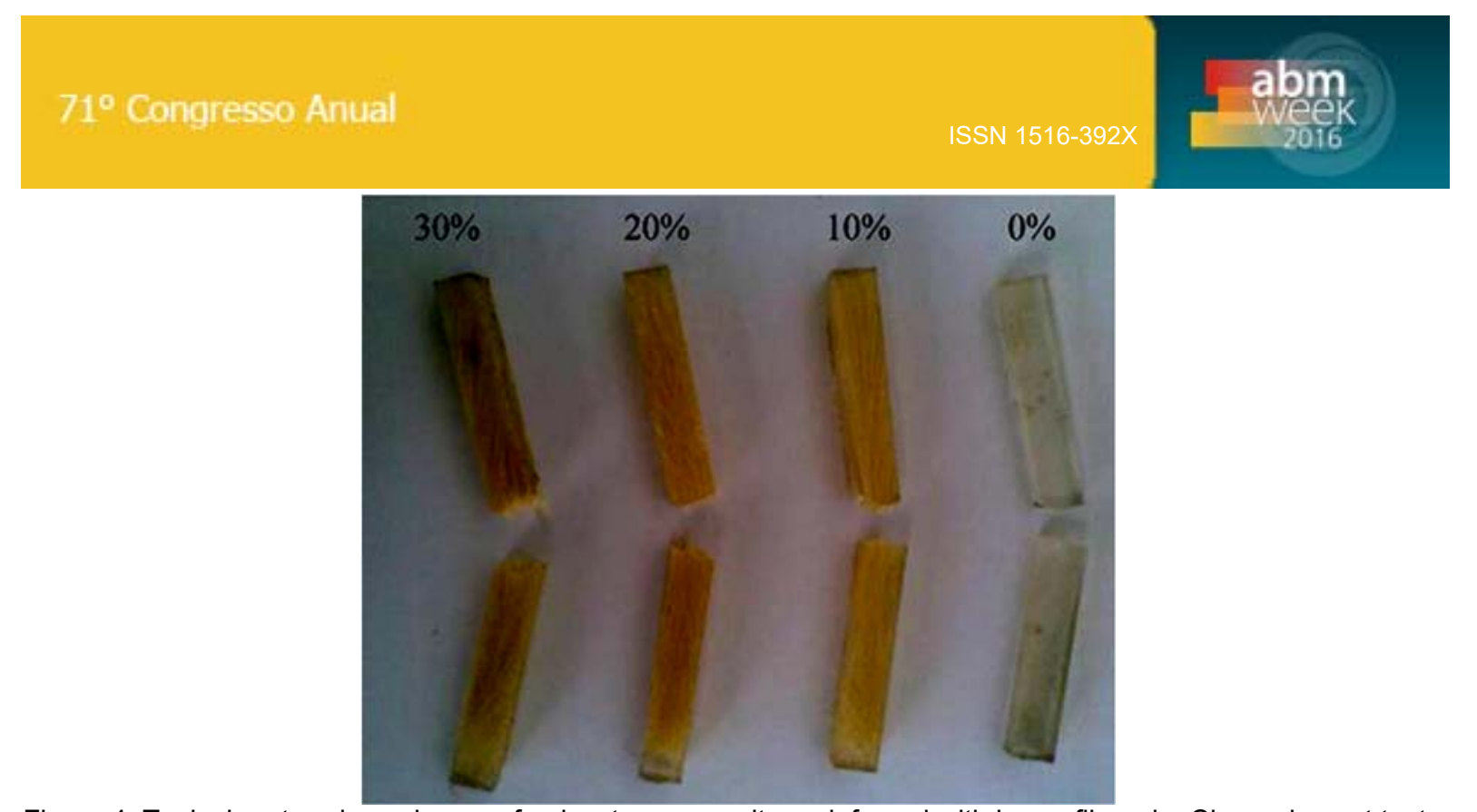

Figure 4. Typical ruptured specimens of polyester composites reinforced with hemp fibers by Charpy impact tests.

Even with $10 \%$ of fiber, the rupture is no longer completely transversal. This indicates that the cracks nucleated at the notch will initially propagate transversally through the matrix, as expected in a monolithic polymer. However, when the crack reaches a fiber, the rupture will proceed through the interface. As a consequence, after the Charpy hammer hit the specimen, some long fibers will be pulled out from the matrix but will not break, simply bend. In fact, for volume fractions of fiber above $10 \%$, some specimens are not separated at all. For these amounts of fibers, part of the specimen was bent enough to allow the hammer to continue its trajectory carrying away the specimen without breaking it into pieces, which is expected in a Charpy test. The value of the impact toughness in this case cannot be compared with others in which the specimen is totally split apart. Anyway, the fact that a specimen is not completely separated in two parts underestimates the impact toughness. In other words, had all the fibers been broken, the adsorbed impact energy would be even higher.

\section{CONCLUSIONS}

There is a significant increase in energy absorbed in Charpy impact tests with the incorporation of hemp fibers in a polyester matrix composite. The weak interface between the hemp fibers and the polyester matrix contributes greatly to increase the impact energy by changing the cracks trajectory in the composite. Most of this increase in toughness is apparently due to the low hemp fiber/ polyester matrix interfacial shear stress. This results in a higher absorbed energy as a consequence of a longitudinal propagation of the cracks throughout the interface, which generates larger rupture areas, as compared to a transversal fracture.

\section{REFERENCES}

1 Aquino, R. C. M. P.; Almeida, J. R. M; Monteiro, S.N. (2005). Análise do Compósito de Piaçava/Resina poliéster, como substituto da Madeira. In: $60^{\circ}$ Congresso Anual da Associação Brasileira de Metalurgia e Materiais - ABM, 24-27 de julho de 2006, Belo Horizonte, MG, Brasil.

2 Hull, D.; Clyne, T. W. (1996) An Introduction to Composite Materials, 2a ed., Cambridge: Cambridge Univ. Press.

3 Monteiro, S.N, Costa, L.L., Santafé, H.P.G.,(2008) Tenacidade ao impacto Charpy de compósito epoxídico reforçado com fibras de coco, In: CBECIMAT - CONGRESSO 
BRASILEIRO DE ENGENHARIA E CIÊNCIA DOS MATERIAIS, outubro de 2008, Porto de Galinha - PE - Brasil.p. 1-12.

4 Bledzki, A.K.; Gassan, J. (1999) Composites reinforced with cellulose-based fibres. Prog. Polym. Sci, v. 24, p. 221-274.

5 Monteiro, S.N.; Lopes, F.P.D.; Ferreira, A.S.; Nascimento, D.C.O. (2009a) Natural fiber polymer matrix composites: cheaper, tougher and environmentally friendly. JOM, v. 61, n. 1 , p. $17-22$

6 Leão, A. L.; F.X., Frollini, E. (1997) Lignocellulose-Plastics Composites, plastic composite. USP \& UNESP.

7 Joseph, A.; Sreekala, M. S.; Oomens, Z.; Koshy, P.; Tohomas, S. A. (2002) “ A comparison of the mechanical properties of phenol formaldehyde composites reinforced with banana fibre and glass fibres". Composites Science and Technology, v. 62, p. 185768, 2002

8 Monteiro, S.N., Lopes, F.P.D., (2007) Ensaios de impacto em compósito polimérico reforçado com fibras de curauá - In: $62^{\circ}$ CONGRESSO ANUAL DO CONGRESSO ANUAL DA ASSOCIAÇÃO BRASILEIRA DE METALURGIA E MATERIAIS ,ABM, julho de 2007, Vitória, ES. p. 1-10

9 Yue, C.Y.; Looi, H.C; Quel, M.Y. (2005) Assessment of Fibre-Matrix Adhesion and Interfacial Properties Using the Pullout Test. Int. J. Adhesion and Adhesives, v. 15, p. 73-80, 1995.

10 Monteiro S.N; Margem F. M; Neto, J.B. Evaluation of the interfacial strength of ramie fibers in polyester matrix composites, TMS 2010 Annual Meeting \& Exhibition, February 14-18, 2010 - Washington State Convention Center, Seattle, WA.

11 Crocker, J., "Natural materials innovative natural composites". Materials Tecnology, 2-3 (2008) 174-178.

12 K.C.M. Nair, S.M. Diwan, S. Thomas, "Tensile properties of short sisal fiber reinforced polystyrene composites”, J. Appl. Polym. Sci., 60(9) (1996) 1483-1497.

13 P.V. Joseph, K. Joseph, S. Thomas, "Short sisal fiber reinforced polypropylene composites: the role of interface modification on ultimate properties". Compos. Interf., 92(2) (2002) 171-205.

14 S.N. Monteiro, W.P. Inacio, F.P.D. Lopes, L.L. Costa, L.F.L. Santos Jr., "Characterization of the critical length of sisal fibers for polyester composite reinforcement", Proceedings of Characterization of Minerals, Metals \& Materials - TMS Conference, (San Francisco, USA, March, 2009) 1-8.

15 S.Y. Fu, B. Lauke, E. Mäder, X. Hu and C.Y. Yue, "Fracture resistance of short-glassfiber-reinforced and short-carbon-fiber-reinforced poly-propylene under charpy impact load and dependence on processing", J. Mater. Process. Technol., 89/90 (1999), 501507.

16 S.N. Monteiro, R.C.M.P. Aquino, F.P.D. Lopes, E.A. Carvalho and J.R.M. d'Almeida, "Charpy impact notch toughness of piassava fibers reinforced polyester matrix composites" (in Portuguese), Rev. Mater., 11(3) (2006) 204-210.

17 S.N. Monteiro, R.C.M.P. Aquino, F.P.D. Lopes, E.A. Carvalho and J.R.M. d'Almeida, "Charpy impact notch toughness of piassava fibers reinforced polyester matrix composites" (in Portuguese), Rev. Mater., 11(3) (2006) 204-210. 